https://doi.org/10.46813/2021-131-110

\title{
HARDWARE AND SOFTWARE COMPLEX FOR MEASURING HARD X-RAY RADIATION ON THE TORSATRON "URAGAN-2M"
}

\author{
S.P. Gubarev, A.V. Klosovsky, G.P. Opaleva, V.S. Taran, M.I. Zolototrubova \\ Institute of Plasma Physics, National Science Center "Kharkov Institute of Physics and \\ Technology”, Kharkiv, Ukraine
}

E-mail: gubarev@kipt.kharkov.ua

This paper presents an automated measuring system for radiation monitoring and measurement of hard X-ray radiation in real time on the "Uragan-2M" torsatron. The system includes an ionizing radiation detector based on a scintillator and a photomultiplier tube, equipment for preliminary processing and normalization of detector signals, and a microcontroller unit for control, measurement and processing.

PACS: 52.70.LA

\section{INTRODUCTION}

An important area of physical research is the study of hard X-rays. An essential factor is the unfavorable effect of ionizing $\mathrm{X}$-ray radiation on the health of service personnel during experimental studies.

In particular, the task of measuring and registration hard X-ray radiation during each working pulse in the experimental zone $2 \mathrm{M}$ torsatron "Uragan-2M" in real time becomes urgent.

For the detection of X-ray is necessary to use special receivers [1-3]. An example of such detectors is a scintillator together with a photomultiplier tube (PMT).

The automated measuring system based on a microcontroller was developed for measuring and registration hard X-ray radiation during each working pulse in real time (Fig. 1).

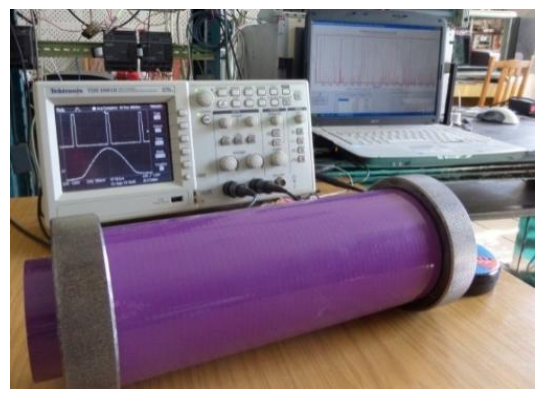

Fig. 1. X-ray measuring device

The features of the experimental work of the torsatron"Uragan-2M" were taken into account in. the development of the device.

Structurally, the meter is placed inside a cylindrical metal massive magnetic container to protect the Photomultiplier Tube Module (PTM) from strong magnetic fields in experimentalsetup. A scintillator is located in the container window.The scintillator together with the PMTis an X-ray detector. In addition, the container contains equipment for pre-processing and normalization of signals from an analog ionizing radiation detector, a microprocessor controller and power supply.

The PMT is powered from an external high-voltage power source. The developed system is a set of hardware and software, organizationally united and integrated into the measuring system of the torsatrone "Uragan-2M". The measuring system allows automatic registration the dependence of the change in radiation intensity in real time mode and to determine the energy spectrum of hard $\mathrm{X}$-ray radiation on an experimental physical setup.

\section{MAIN PART}

The main features of the experimental operation of the torsatron"Uragan-2M" were taken into account when developing the measuring system:

- the pulse duration of hard X-ray detector $\geq 5 \mu \mathrm{s}$;

- the life time of the magnetic field - $4 \mathrm{~s}$;

- plasma life time - 40...60 ms.

The expected maximum of hard X-ray radiation is in the region of the magnetic field decay (time $\sim 0.5 \mathrm{~s}$ ).

It was necessary to provide the following functionswhen creating a measuring system:

- providing automatic measurement of the intensity of X-ray radiation in torsatron during the working discharge ("Intensity" mode);

- ensuring the automatic acquisition of the energy spectrum of the ionizing;

- radiation during the working discharge of the torsatron ("Spectrum" mode);

- synchronization with the "Uragan-2M" control stand (opto-isolation);

- analog-to-digital conversion (ADC) of intensity signals radiation synchronously with the appearance of quantum of ionizing radiation;

- formation of an array of registered data for one working pulse - 64000 16-bit words;

- organization of software-configurable clocking;

- providing an algorithm of exchange of signals with a preprocessing unit;

- fixing the time of implementation of each adc conversion (in the "intensity" mode);

- automatic decomposition of the fixed amplitudes of radiation signals by 1024 channels radiation;

- signals by 1024 channels for constructing the energy spectrum (software amplitude analyzer);

- providing capacity of each spectral channel (memory cell) - 65536 samples; 
- monitoring the modes of the photomultiplier unit;

- implementation of data exchange with computers of the local network;

- selection and indication of operating modes;

- providing in-circuit programming.

Taking into account the listed features and existing developments [4], an automated measuring system for registration hard X-rays was developed and implemented at the Institute of Plasma Physics of the NSC KIPT on the stellarator "Uragan-2M".

The developed system consists from the ionizing radiation detector, equipment for preliminary processing and normalization of signals of analog charge detector, and a microcontroller unit for control, measurement and processing. The developed set of programs ensures the interaction of system nodes and elements of computer technology, combined into a single complex.

An inorganic scintillator based on monocrystalline cesium iodide CsI (TI) with a thallium activator with $40 \mathrm{~mm}$ thick is used as an ionizing radiation detector. A photomultiplier tube (PT) serves as a receiver of visible radiation.

Hard X-ray radiation arises at the decay of the magnetic toroidal field when the voltage in the electrical windings is removed at the end of each working pulse of the torsatron.

The functional scheme of equipment for preprocessing and normalization of signals (SPE) is shown in Fig. 2.

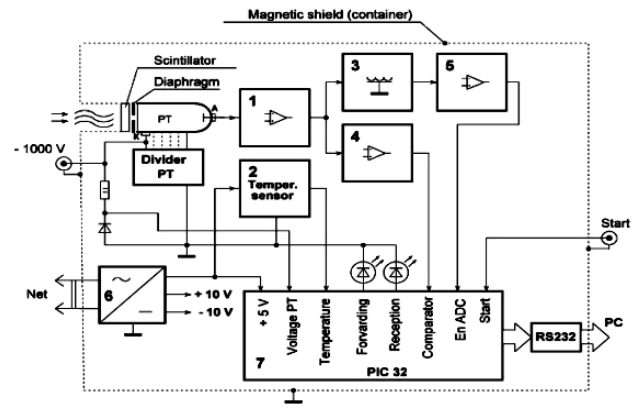

Fig. 2. The functional scheme of equipment for preprocessing and normalization of signals (SPE)

The diagrams of the device operation are shown in Fig. 3.

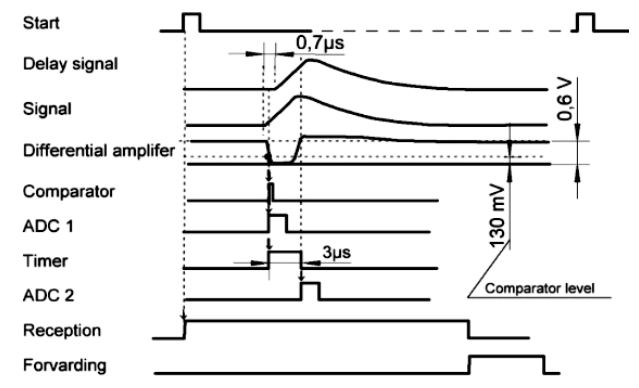

Fig. 3. The diagrams of the device operation

SPE equipment consists of analog units designed to amplify the input signal and generate measuring signals with the required parameters.

The SPE works as follows. When an X-ray quantum enters the scintillator, a flash of visible light occurs. When it hits the photomultiplier of the photocathode, it causes a significant increase in the electron current on the dynodes. A current pulse appears at the exit from the PMT anode. This current signal is fed to a chargesensitive preamplifier (1) (see Fig. 2).

At the output of the amplifier, a pulse is formed with a steep (less than $1 \mu \mathrm{s})$ front edge and a shallow $(5 \ldots 10 \mu \mathrm{s})$ back edge (Signal) (see Fig. 3). Then the signal is fed to the delay line (3) and to the differential amplifier (4) simultaneously.

A circuit with an analog delay is used to eliminate the "zero" level bias in the measurements, which occurs due to the low-frequency noises of the amplifier and modulates the useful signal.

From the delay line, the signal is fed to an amplifier (5) to form the front and normalization in amplitude.

A differentiating amplifier inverts the signal and sharpens its edge. The pulses from the differential amplifier are fed to the input of the comparator of the microcontroller (7). They start the measurement cycle of the analog-to-digital converter (ADC).

The temperature sensor is placed inside the container (2) to compensate the photomultiplier's sensitivity from temperature changes. The measuring system is powered by a voltage converter (6).

The automated registration of radiation and the provision of interconnections of individual elements of the measuring system are carried out by an intelligent digital controller. It was necessary to take into account the possibility of ensuring the following critical parameters for choosing the integrated microcontroller:

- the number of high-speed ADC channels - 1 (according to the number of available detectors of ionizing radiation);

- the number of technological ADC channels - 2;

- maximum speed - at least one measurement in $5 \mu \mathrm{s}$; - data collection period - $0.5 \mathrm{~s}$.

(time of magnetic field decay);

- accuracy - about $0.1 \%$ ( 10-bit conversion);

- ensuring communication of the device with a personal computer for control of operation modes and transmission recorded data for subsequent graphic visualization and documentation; conversion time of the measuring channel of the ADC module $(\mathrm{T} \leq 5 \mu \mathrm{s})$;

- Sufficiently large internal memory: $M \geq 128.000$ bytes / 102.400 10-bit words.

The modern integrated microcontroller manufactured by Microchip of the PIC32MX series [5] corresponds these requirements. This controller includes a powerful processor with graphics, large memory and a large number of peripheral modules.

The block scheme of the microcontroller unit for control, measurement and processing is shown in Fig. 4.

Accepted abbreviations:

Upt - PMT supply voltage;

PT - PMT module;

X-Ray - signal of radiation from the PMT;

DA - differential amplifier;

TMR - timer module;

ADC - ADC module;

CPU - processor module;

UART - module of asynchronous transceiver; ICD-3 - in-circuit programmer-debugger. 
The package of original programs has been developed to ensure the functioning of the hardware and software complex. Each of the package programs installs the mode and controls the operation of specific nodes and peripheral modules, presented in the block diagram (see Fig. 4).

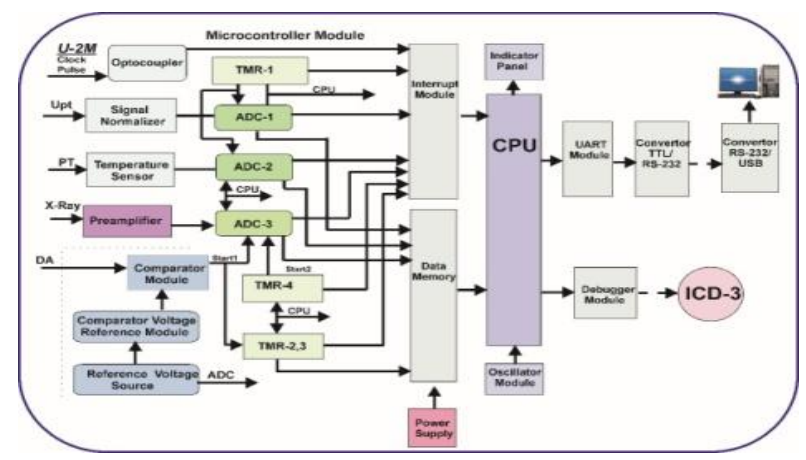

Fig. 4. The block diagram of the microcontroller

The operation of the controller is synchronized in time with the operation of the systems of the "Uragan-2M" experimental setup by supplying the Clock Pulse signal from the setup's synchronic rack. To eliminate the galvanic connection between the installation and the measuring system. The optical isolation unit is used to eliminate the galvanic connection between the installation and the measuring system.

The controller includes two technological measurement channels. The ADC-1 module measures the high voltage of the PMT, which fed to the ADC input through the signal normalizer. The ADC-2 module controls the temperature of the PMT container. An analog temperature sensor is used as a sensor. The operation of the ADC- 1 and ADC- 2 modules is synchronized by the programmable timer TMR-1. The control carried out by the CPU processor.

The Comparator Voltage Reference Module (CVREF) is used in conjunction with the Reference Voltage source to provide software setting for the Comparator Module.

When the Clock Pulse signal arrives at the interrupt module of the controller, a command is generated to enable the start of the ADC modules.

The X-ray signals from the PMT, amplified by the 'Preamplifier', are fed to the input of the ADC-3 module for cyclic conversion into digital codes. The speed and modes of sampling and storage of the signal for conversion are set by software in accordance with the scenario of experiments and the parameters of the ionizing radiation signal. The ADC conversion is triggered at an arbitrary time moment corresponding to the occurrence of each single signal from the X-ray detector. Each conversion result and the time of its receipt are recorded and stored in the controller memory (Data Memory), forming a corresponding array of registered data in real time (in the "Intensity" mode).

In this case, 20.000 results of intensity measurements and 20.000 values of the time of their measurement are recorded in the controller's memory ("Intensity" array).
A 32-bit TMR-2-3 timer module with a clock frequency of $80 \mathrm{MHz}$ was used to ensure high accuracy of fixing a set of values of the time of occurrence of the moments of measurement of each signal from the detector. Reading of each current fixed time value is carried out without stopping the timer.

The TMR-4 module synchronizes the work of the ADC-3 with the delay line.

The microprocessor is clocked by the built-in software generator Oscillator Module.

In the "Spectrum" operating mode, automatic decomposition of the fixed amplitudes of the radiation signals into 1024 channels is performed to build the energy spectrum (software amplitude analyzer). Each channel is a 16-bit location in the allocated data memory area. The number of channels corresponds to the number of possible measured values of the X-ray signal amplitudes (when using a 10-bit ADC). In other words, when registering each emerging radiation quantum, the cell contents are incremented with a number corresponding to one of the 1024 measured amplitudes. As a result, a data array of 1024 values is formed, each of which corresponds to the number of registered signals with an amplitude corresponding to the cell number ("Spectrum" array).

When displaying the resulting array and the "Intensity" array on the monitor screen, the energy spectrum of the radiation is obtained for the corresponding exposure time and the graph of the change in the radiation intensity during the data collection time.

Using a microcontroller UART module and a MAX232 serial integrated driver, a COM port is implemented that supports the exchange protocol and RS-232 interface.

The Indicator Panel reflects the current operating modes of the measuring system.

The end of the process of accumulation and processing of data occurs when the array is filled or by the command of the microcontroller timer programmatically. At the end of the full measurement cycle, at the command of the microcontroller, the entire data array is automatically sent via the RS-232 serial interface to the local network computer for graphical visualization and documentation of the registered values of the intensity and energy spectrum of X-ray radiation.

The microcontroller is equipped with an in-circuit programming module (Debugger Module), which allows writing programs to the controller's memory and editing them through an external connector without opening the device. For these purposes, the ICD-3 programmer-debugger (Microchip Co) is used. In Fig. 5 shows the programmer and the mounted printed circuit board of the microcontroller control unit.

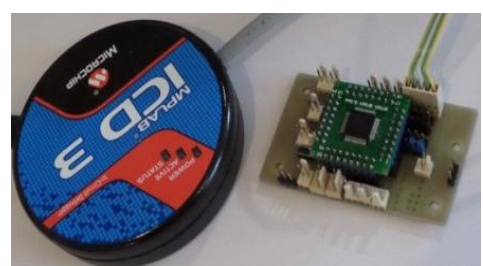

Fig. 5. Programmer and printed circuit board with microcontroller 
The measuring device is powered from the $220 \mathrm{~V} \mathrm{~Hz}$ $\mathrm{AC}$ mains. The power consumption is $5 \mathrm{~W}$.

The software (SW) of the complex consists of three software packages. The first is written in the C32 language in the MPLAB $\mathrm{X}$ environment under the control of the Windows 10 operating system. It provides the operation of the $\mathrm{X}$-ray radiation recording equipment, processing and data transmission to the local network via the RS-232 serial interface (COM port). The second one display the obtained arrays "Spectrum" and "Intensity" on the monitor screen in the Builder 6 environment.The third software package is the Test kit. Test programs are designed for debugging software settings device. The package ensures the work of the debug bench. The processing of the obtained results is carried out using the mathematical packages Spectrum, Origin 9, MATLAB, which allow you to quickly process experimental data.

To illustrate the operation of the measuring system, Fig. 6 shows an example automatically constructed spectrum of the registered ionizing radiation of the isotope ${ }^{137} \mathrm{Cs}$ and a graph of the measured intensity of its radiation for 5 seconds.

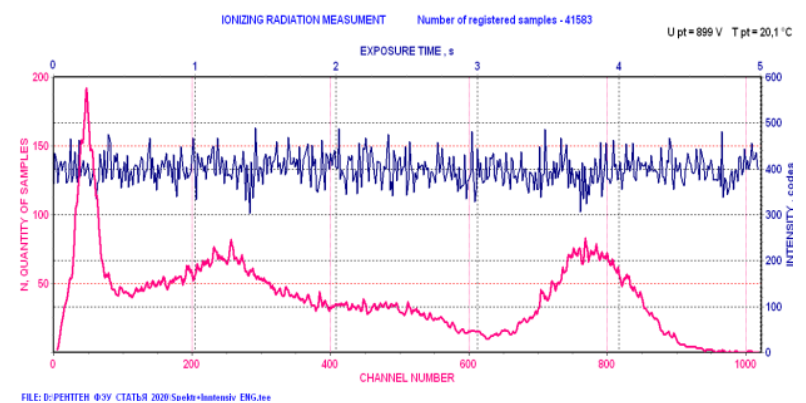

Fig 6. The recorder emission the isotope ${ }^{137}$ Cs spectrum

\section{CONCLUSIONS}

An inexpensive measuring system developed at the Institute of Plasma Physics of the NSC KIPT from available components, based on a high-speed integrated microcontroller for controlling hard X-ray radiation, allows monitoring the intensity of $\mathrm{X}$-ray radiation in the experimental zone and obtains its energy spectrum.

Software development and debugging tools are available from open sources from the microcontroller manufacturer (Microchip Technology Inc.), which allows you to edit the developed application software and adapt the functioning of the measuring system to the real operating conditions of a particular object.

The presence of such equipment in the arsenal of technical support of experimental installations is undoubtedly useful and can be recommended for use for operating under conditions of the occurrence of ionizing radiation.

\section{REFERENCES}

1. V.K. Lyapidevskii. Methods for radiations detecting. M.: "Energoatomizdat",1987.

2. Yu.A. Budagov et al. Ionization measurements in high energy physics. M.: "Atomizdat", 1988.

3. A.V. Bushuev, A.F. Kozhin, E.V. Petrova, T.B. Aleeva, V.N. Zubarev. Methods and instruments for measuring nuclear materials / Laboratory workshop. M.: "Nrnumephi". 2011, 156 p.

4. S.P. Gubarev, A.V. Klosovsky, A.V. Leonovych, G.P. Opaleva, V.S. Taran, M.I. Zolototrubova. Development of an automated radiation control system based onsemiconductor ionizing radiation detectors // Problems of Atomic Science and Technology. Series «Plasma Physics» (118). 2018, № 6, p. 285-288.

5. Kevin Lynch, Nicholas Marchuk, Matthew L. Elwin. Embedded Computing and Mechatronics with the PIC32 Microcontroller, 2015.

Article received 05.01.2021

\title{
АППАРАТНО-ПРОГРАММНЫЙ КОМПЛЕКС ДЛЯ ИЗМЕРЕНИЯ ЖЕСТКОГО РЕНТГЕНОВСКОГО ИЗЛУЧЕНИЯ НА ТОРСАТРОНЕ «УРАГАН-2М»
}

\author{
С.П. Губарев, А.В. Клосовский, Г.П. Опалева, В.С. Таран, М.И. Золототрубова
}

\begin{abstract}
Представлена автоматизированная измерительная система для осуществления радиационного контроля и измерения жесткого рентгеновского излучения в реальном масштабе времени на торсатроне «Ураган-2М». Система включает в себя: детектор ионизирующего излучения на основе сцинтиллятора и фотоэлектронного умножителя, аппаратуру предварительной обработки и нормализации сигналов детектора, микроконтроллерный блок управления, измерения и обработки.
\end{abstract}

\section{АПАРАТНО-ПРОГРАМНИЙ КОМПЛЕКС ДЛЯ ВИМІРЮВАННЯ ЖОРСТКОГО РЕНТГЕНІВСЬКОГО ВИПРОМІНЮВАННЯ НА ТОРСАТРОНІ «УРАГАН-2М»}

\section{С.П. Губарєв, А.В. Клосовський, Г.П. Опалєва, В.С. Таран, М.І. Золототрубова}

Представлена автоматизована вимірювальна система для здійснення радіаційного контролю та вимірювання жорсткого рентгенівського випромінювання в реальному масштабі часу на торсатроні «Ураган-2М». Система включає в себе: детектор іонізуючого випромінювання на основі сцинтилятора i фотоелектронного помножувача, апаратуру попередньої обробки і нормалізації сигналів детектора, мікроконтролерний блок управління, вимірювання і обробки. 